\title{
Synthesis and Characterization of Cu-Doped Zirconium Titanate as A Potential Visible- Light Responsive Photocatalyst
}

\author{
Katarina Rachma Andita, Rian Kurniawan, and Akhmad Syoufian* \\ Department of Chemistry, Faculty of Mathematics and Natural Sciences, Universitas Gadjah Mada, \\ Sekip Utara, Yogyakarta 55281, Indonesia
}

* Corresponding author:

email:akhmadsyoufian@ugm.ac.id

Received: October 18, 2018

Accepted: December 22, 2018

DOI: $10.22146 / \mathrm{ijc} .39778$

\begin{abstract}
Synthesis and characterization of $\mathrm{Cu}$-doped zirconium titanate as a potential visible-light responsive photocatalyst had been conducted. Titanium tetraisopropoxide (TTIP) was used as a precursor of Ti source, reacted to $\mathrm{ZrO}_{2}$ powder and $\mathrm{CuSO}_{4} \cdot 5 \mathrm{H}_{2} \mathrm{O}$ with various $C u$ concentrations of $0,1,3,5,7$ and $9 \%(w / w)$ by sol-gel method. Zirconium titanate with Cu concentration of 5\% was calcined at various temperatures of 500, 700 and $900^{\circ} \mathrm{C}$. All materials were characterized by using XRD, FTIR, SRUV, and SEM-EDX. The characterization proved that the materials were potential as a model of visible-light responsive photocatalyst. Composite with optimum bandgap energy $\left(E_{g}\right)$ was obtained at $5 \% \mathrm{Cu}$ content after $500{ }^{\circ} \mathrm{C}$ with an absorption edge wavelength of $431.93 \mathrm{~nm}$ and the bandgap of $2.87 \mathrm{eV}$.
\end{abstract}

Keywords: copper; dopant; Cu-doped $\mathrm{ZrTiO}_{4}$; photocatalyst; sol-gel

\section{- INTRODUCTION}

Lately, there has been an increasing number of developments in photocatalyst technology. One example of photocatalyst technology usage is to decompose such as textile industrial waste. That waste contains methylene blue that is difficult to decompose naturally [1]. Titania $\left(\mathrm{TiO}_{2}\right)$ is a metal oxide semiconductor that has been widely studied as a photocatalyst. $\mathrm{TiO}_{2}$ has relatively high redox potential, relatively high chemical stability, photocorrosion resistance, strong oxidizing agent, economical price, and non-toxic properties. The bandgap energy of $\mathrm{TiO}_{2}$ (anatase) is $3.2 \mathrm{eV}$ with a UV light wavelength that is approximately $\lambda<385 \mathrm{~nm}$ [2-4]. This is the major problem of $\mathrm{TiO}_{2}$ based photocatalyst under sunlight application. Only $4-5 \%$ of sunlight is in the ultraviolet region while $45 \%$ is in the visible-light region [5]. Efforts to optimize the use of sunlight are carried out by shifting $\mathrm{TiO}_{2}$ uptake to the visible-light region, minimizing the $\mathrm{E}_{\mathrm{g}}$ value so that it has higher photocatalytic activity with better performance. The modification process to shift the absorption of $\mathrm{TiO}_{2}$ to longer wavelength can be carried out through doping method. Doping metal ion can be transition metal cations such as $\mathrm{Cu}^{2+}$. High recombination rate of electrons and holes in $\mathrm{TiO}_{2}$ can be inhibited by the dopants as electron-trapper [6]. The reduction potential of transition metal $\mathrm{Cu}^{2+}$ is as high as $0.34 \mathrm{~V}$ and $\mathrm{Cu}$ electronegativity being higher than Ti makes it easier to attract electrons [7].

Low $\mathrm{E}_{\mathrm{g}}$ of $\mathrm{TiO}_{2}$ makes itself responsive towards the visible-light. In addition to $\mathrm{TiO}_{2}$, the $\mathrm{ZrO}_{2}$ semiconductor can also be used as an effective photocatalyst with a bandgap energy of 3.2-5.1 eV. $\mathrm{ZrO}_{2}$ has high thermal stability, resistant to corrosion, nontoxic and eco-friendly [8-9]. But the recombination process decreases $\mathrm{ZrO}_{2}$ photocatalytic efficiency. Efforts made to overcome this involves doping it with metal or coupling it with another semiconductor that has small $\mathrm{E}_{\mathrm{g}}$ so that it can prevent electron-hole recombination [1011 .

In this research, $\mathrm{Cu}$-doped $\mathrm{ZrTiO}_{4}$ material will be synthesized by sol-gel method. The advantages of this method are high purity of the products, low process temperature, the ability to control the resulted crystal phase, high resistance of the composites towards solvent as well as high thermal and mechanical stability [12-13]. Modification through sol-gel method has resulted in the formation of homogenous composites with smooth 
surface [14]. The parameters that would be investigated in this study were the $\mathrm{Cu}$ concentration and the calcination temperature.

\section{- EXPERIMENTAL SECTION}

\section{Materials}

Titanium(IV) isopropoxide (TTIP) (97\%, SigmaAldrich) and zirconia powder $\left(\mathrm{ZrO}_{2}\right)$ (Jiaozuo Huasu) were used as precursors for synthesizing the photocatalyst material, copper(II) sulfate pentahydrate $\left(\mathrm{CuSO}_{4} \cdot 5 \mathrm{H}_{2} \mathrm{O}\right)$ (Merck), absolute ethanol (PA, Merck) and demineralized water (Jaya Sentosa) were used in sol-gel method.

\section{Instrumentation}

X-ray powder diffraction (XRD) PANalytical X'Pert PRO MRD instrument with $\mathrm{CuKa}$ radiation was used to analyze the crystal structure. Fourier-Transform Infrared spectrophotometer (FT-IR) analysis was conducted using Thermo Nicolet iS10. Specular Reflectance UV-Vis spectrophotometer UV1700 Pharmaspec (SR-UV) was used to analyze the absorption of the materials. The morphology and the composition of elements in $\mathrm{Cu}$ doped $\mathrm{ZrTiO}_{4}$ were measured using Scanning Electron Microscope-Energy Dispersive X-Ray spectrometer (SEM-EDX) JSM-6510LA with an accelerating voltage of $2000 \mathrm{kV}$.

\section{Procedure}

Synthesis of $\mathrm{Cu}$-doped $\mathrm{ZrTiO}_{4}$ through sol-gel method was done by adding $25 \mathrm{~mL}$ of absolute ethanol dropwise in $2.5 \mathrm{~mL}$ of TTIP and then stirred for $30 \mathrm{~min}$. Next, $\mathrm{CuSO}_{4} \cdot 5 \mathrm{H}_{2} \mathrm{O}$ salts (concentration of $\mathrm{Cu}$ dopant: 0 , $1,3,5,7,9 \%(\mathrm{w} / \mathrm{w}))$ and $1 \mathrm{~g}$ of $\mathrm{ZrO}_{2}$ powder were dissolved together in $25 \mathrm{~mL}$ of demineralized water, then dropped slowly into the Ti precursor until the gel was formed [15]. It was then stirred again for $30 \mathrm{~min}$. Afterward, the mixture was centrifuged for $1 \mathrm{~h}$ at 2000 $\mathrm{rpm}$ to separate the solid. The obtained solid was dried in the open air for $24 \mathrm{~h}$ and then heated at $80^{\circ} \mathrm{C}$ for $24 \mathrm{~h}$. Finally, the material was calcined at 500,700 and $900{ }^{\circ} \mathrm{C}$ for $4 \mathrm{~h}$. All materials were characterized by using XRD, FTIR, SRUV, and SEM-EDX.

\section{- RESULTS AND DISCUSSION}

Fig. 1 shows the diffraction pattern of the $\mathrm{Cu}$-doped $\mathrm{ZrTiO}_{4}$ with various $\mathrm{Cu}$ concentrations after calcination at $500{ }^{\circ} \mathrm{C}$. Characteristic peak of $\mathrm{TiO}_{2}$ anatase (JCPDS: 01-084-1286) appeared at $25^{\circ}\left(\mathrm{d}_{101}\right)$ and $48^{\circ}\left(\mathrm{d}_{200}\right)$. On the other hand, $\mathrm{ZrO}_{2}$ monoclinic (JCPDS: 01-088-2390) appeared in $\mathrm{ZrO}_{2}$ reference at $28^{\circ}\left(\mathrm{d}_{-111}\right), 31^{\circ}\left(\mathrm{d}_{111}\right), 34^{\circ}$ $\left(\mathrm{d}_{002}\right)$ and $51^{\circ}\left(\mathrm{d}_{220}\right)$. The anatase peak at $25^{\circ}\left(\mathrm{d}_{101}\right)$ showed a change in intensity along with $\mathrm{Cu}$ dopant concentration. The intensity of anatase decreased as copper concentration increased up to $5 \%$, and became stagnant at above $5 \%$. The copper dopant as impurity inhibits anatase transformation of $\mathrm{TiO}_{2}$ from the amorphous sol-gel product.

Fig. 2 shows the diffraction pattern of $5 \% \mathrm{Cu}$ doped $\mathrm{ZrTiO}_{4}$ calcined at various temperatures with the reference materials of $\mathrm{TiO}_{2}$ and $\mathrm{ZrO}_{2}$ after $500{ }^{\circ} \mathrm{C}$ calcination. The diffraction pattern of $\mathrm{TiO}_{2}$ and $\mathrm{ZrO}_{2}$ calcined at $500{ }^{\circ} \mathrm{C}$ indicates the presence of anatase and monoclinic phase. $\mathrm{Cu}$-doped $\mathrm{ZrTiO}_{4}$ after $900{ }^{\circ} \mathrm{C}$ calcination showed characteristic rutile pattern (JCPDS: 01-076-1938) at $27^{\circ}\left(\mathrm{d}_{110}\right), 36^{\circ}\left(\mathrm{d}_{101}\right), 41^{\circ}\left(\mathrm{d}_{111}\right)$ and $54^{\circ}$ $\left(\mathrm{d}_{211}\right)$, while intensity of anatase pattern at $25^{\circ}\left(\mathrm{d}_{101}\right)$ and $48^{\circ}\left(\mathrm{d}_{200}\right)$ decreased. At $900^{\circ} \mathrm{C}$ calcination, the $\mathrm{Cu}$-doped $\mathrm{ZrTiO}_{4}$ had an anatase peak intensity that decreased significantly in comparison at $700{ }^{\circ} \mathrm{C}$; and the dominant

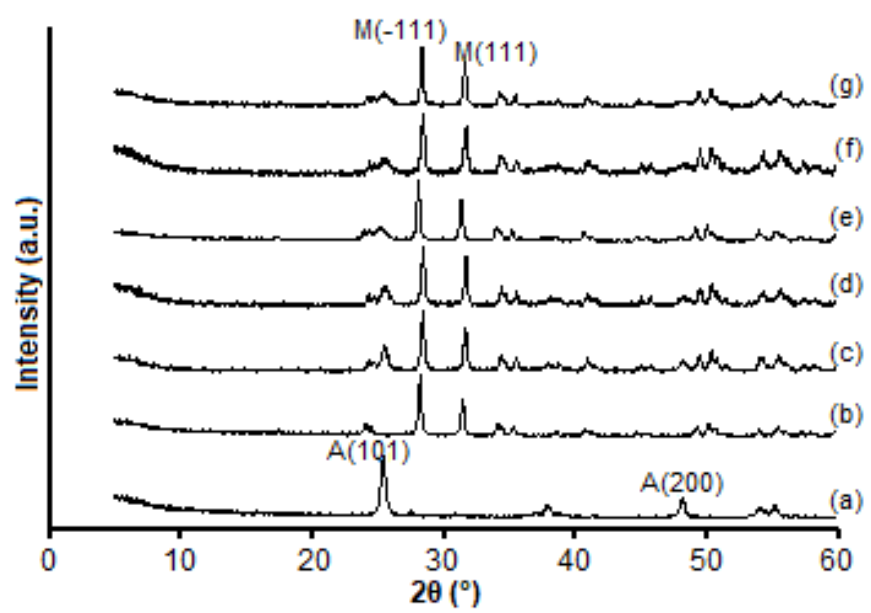

Fig 1. Diffraction pattern of (a) $\mathrm{TiO}_{2}$, (b) $\mathrm{ZrO}_{2}$, and Cudoped $\mathrm{ZrTiO}_{4}$ with (c) 1, (d) 3, (e) 5, (f) 7 and (g) 9\% $(\mathrm{w} / \mathrm{w})$ of $\mathrm{Cu}$ concentration at $500{ }^{\circ} \mathrm{C}$ calcination 


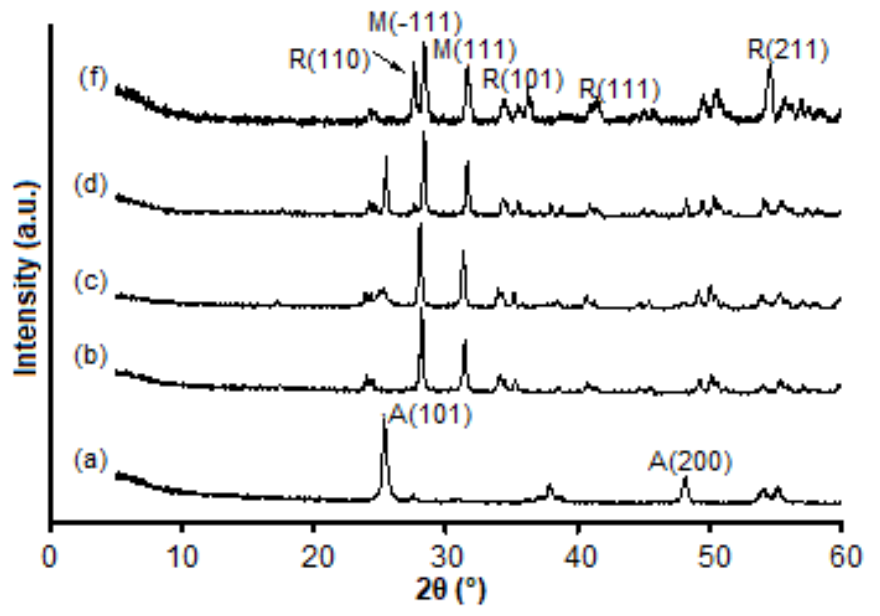

Fig 2. Diffraction pattern of (a) $\mathrm{TiO}_{2} 500{ }^{\circ} \mathrm{C}$, (b) $\mathrm{ZrO}_{2}$ $500{ }^{\circ} \mathrm{C}$ and 5\% Cu-doped $\mathrm{ZrTiO}_{4}$ with (c) 500, (d) 700 and (e) $900{ }^{\circ} \mathrm{C}$ of calcination temperature

rutile phase at $900{ }^{\circ} \mathrm{C}$. This proved that the existence of $\mathrm{ZrO}_{2}$, which was dominant as supporting material, can inhibit anatase transformation to rutile [16].

Fig. 3 shows the FTIR spectra of materials with a various $\mathrm{Cu}$ dopant concentration in $\mathrm{Cu}$-doped $\mathrm{ZrTiO}_{4}$ along with $\mathrm{TiO}_{2}$ and $\mathrm{ZrO}_{2}$ as references. The characteristic peaks around 660 and $581 \mathrm{~cm}^{-1}$ which are the vibrations of $\mathrm{Zr}-\mathrm{O}$ and $\mathrm{Ti}-\mathrm{O}$ bonds [17] tend to change as the $\mathrm{Cu}^{2+}$ dopant concentration increased. This indicates that $\mathrm{Cu}$ metal was successfully doped on the photocatalyst surface.

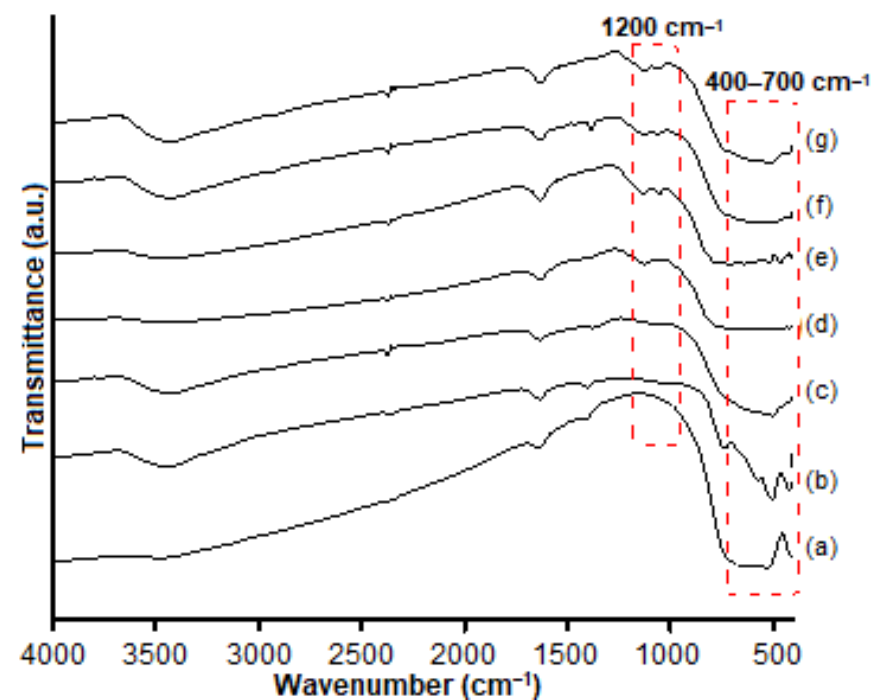

Fig 3. FTIR spectra of (a) $\mathrm{TiO}_{2}$, (b) $\mathrm{ZrO}_{2}$, and $\mathrm{Cu}$-doped $\mathrm{ZrTiO}_{4}$ with (c) 1, (d) 3, (e) 5, (f) 7 and (g) 9\% (w/w) of $\mathrm{Cu}$ concentration at $500{ }^{\circ} \mathrm{C}$ calcination
Absorption at wavenumber 1635 and $3400 \mathrm{~cm}^{-1}$ are the bending and stretching vibrations of $\mathrm{H}_{2} \mathrm{O}$ molecules. There is a vibrational bond that appeared around 1200 $\mathrm{cm}^{-1}$ which shows the vibration of $\mathrm{Cu}-\mathrm{O}-\mathrm{Zr}$ via $\mathrm{Ti}-\mathrm{O}-\mathrm{Zr}$ bridge on the surface of $\mathrm{ZrO}_{2}$. The peak intensity decreased from 3 to $5 \% \mathrm{Cu}$-doped $\mathrm{ZrTiO}_{4}$. The peak intensity of $\mathrm{Cu}-\mathrm{O}-\mathrm{Zr}$ vibration increased as $\mathrm{Cu}$ concentration increased until $5 \%$ and stayed stagnant above $5 \%$. It is believed that the excess $\mathrm{Cu}$ (above 5\%) doped the $\mathrm{ZrTiO}_{4}$ system at the interstitial position or possibly aggregating.

Fig. 4 shows the FTIR spectra of various calcination temperatures $\mathrm{Cu}$-doped $\mathrm{ZrTiO}_{4}$ together with $\mathrm{TiO}_{2}$ and $\mathrm{ZrO}_{2}$ as references. The peak showed the different intensity of $\mathrm{Cu}-\mathrm{O}-\mathrm{Ti}$ or $\mathrm{Cu}-\mathrm{O}-\mathrm{Zr}$ at the wavenumber of $400-700$ and $1200 \mathrm{~cm}^{-1}$ at different temperatures. The intensity decreased when the calcination temperature was $500^{\circ} \mathrm{C}$. The lowest intensity indicates that the material had been doped optimally. The characteristic peak of $\mathrm{Ti}-\mathrm{O}-\mathrm{Ti}$ bond changed at temperature 700 and $900{ }^{\circ} \mathrm{C}$. This is caused by the transformation of anatase to rutile phase. The bond length between the anatase $\mathrm{Ti}-\mathrm{O}$ phases is shorter than the rutile phase $\mathrm{Ti}-\mathrm{O}$, resulting in different vibrational energy.

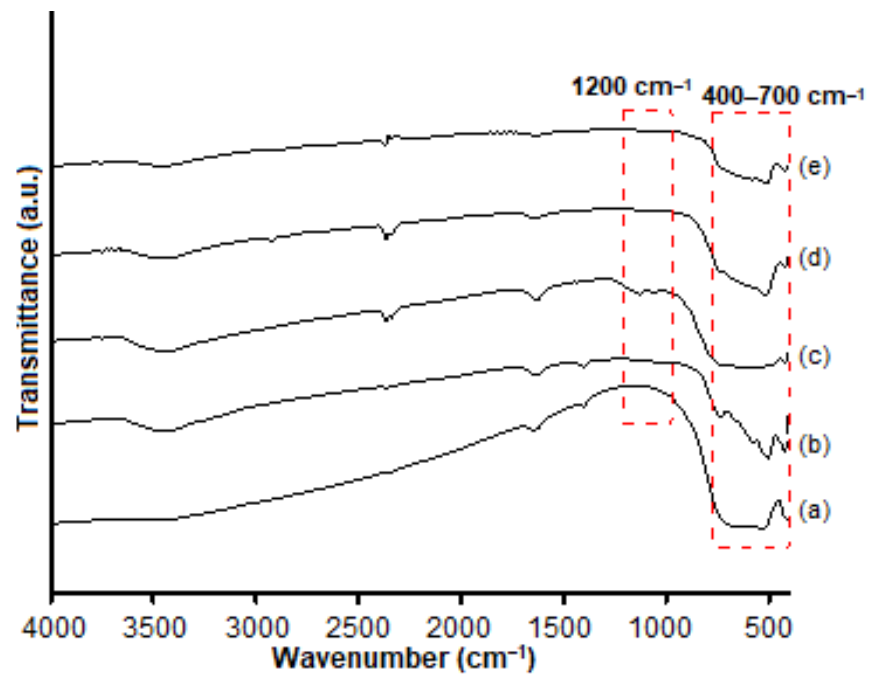

Fig 4. FTIR spectra of (a) $\mathrm{TiO}_{2} 500{ }^{\circ} \mathrm{C}$, (b) $\mathrm{ZrO}_{2} 500{ }^{\circ} \mathrm{C}$, and $5 \% \mathrm{Cu}$-doped $\mathrm{ZrTiO}_{4}$ with (c) 500, (d) 700 and (e) $900{ }^{\circ} \mathrm{C}$ of calcination temperature 
Table 1. Bandgap data of $\mathrm{Cu}$-doped $\mathrm{ZrTiO}_{4}$ with $\mathrm{ZrO}_{2}$ and $\mathrm{TiO}_{2}$

\begin{tabular}{lc}
\hline Sample & $\mathrm{E}_{\mathrm{g}}(\mathrm{eV})$ \\
\hline $\mathrm{ZrO}_{2} 500{ }^{\circ} \mathrm{C}$ & 3.23 \\
$\mathrm{TiO}_{2} 500{ }^{\circ} \mathrm{C}$ & 3.02 \\
$\mathrm{Cu}-\mathrm{ZrTiO}_{4} 1 \% 500^{\circ} \mathrm{C}$ & 3.07 \\
$\mathrm{Cu}-\mathrm{ZrTiO}_{4} 3 \% 500^{\circ} \mathrm{C}$ & 3.06 \\
$\mathrm{Cu}-\mathrm{ZrTiO}_{4} 5 \% 500^{\circ} \mathrm{C}$ & 2.87 \\
$\mathrm{Cu}-\mathrm{ZrTiO}_{4} 5 \% 700^{\circ} \mathrm{C}$ & 2.99 \\
$\mathrm{Cu}-\mathrm{ZrTiO}_{4} 5 \% 900^{\circ} \mathrm{C}$ & 2.93 \\
$\mathrm{Cu}^{\circ}-\mathrm{ZrTiO}_{4} 7 \% 500^{\circ} \mathrm{C}$ & 2.95 \\
$\mathrm{Cu}-\mathrm{ZrTiO}_{4} 9 \% 500^{\circ} \mathrm{C}$ & 2.97 \\
\hline
\end{tabular}

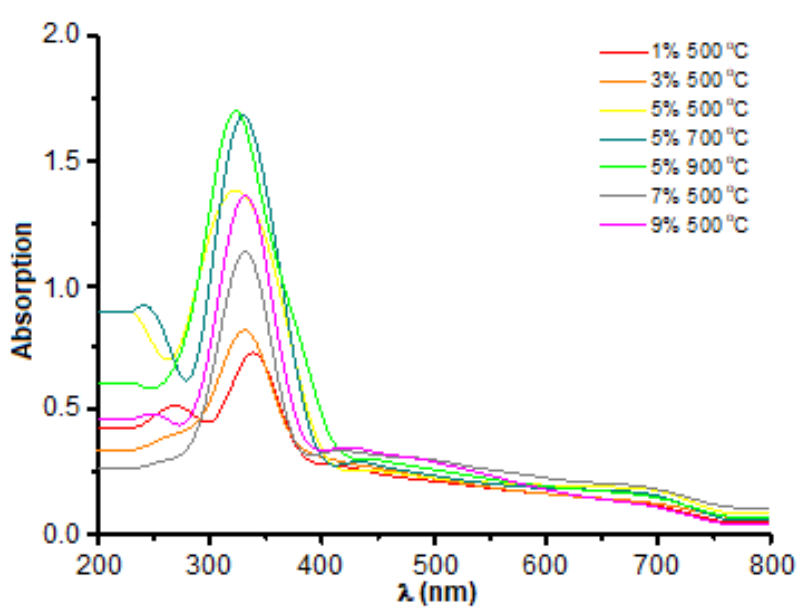

Fig 5. UV-Vis absorption spectra of various $\mathrm{Cu}$-doped $\mathrm{ZrTiO}_{4}$
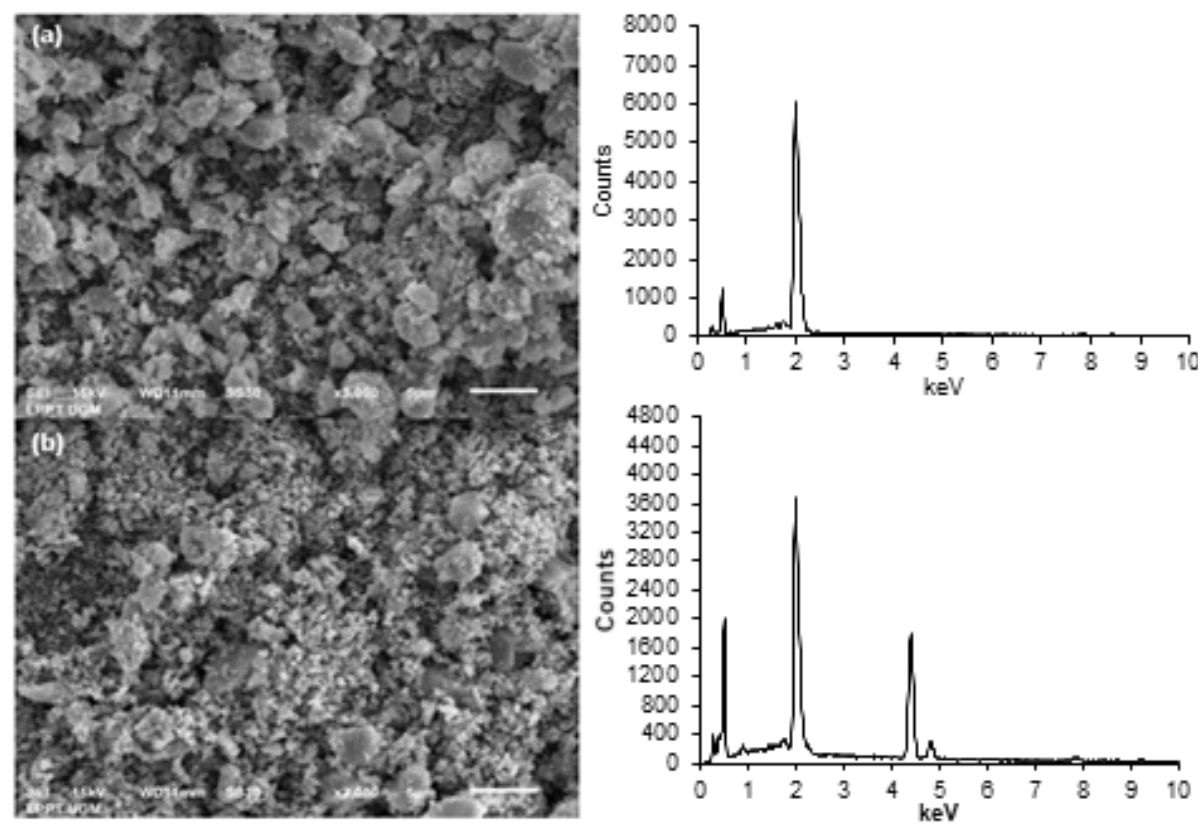

Fig 6. SEM images and EDX spectra of $5 \% \mathrm{Cu}$-doped (a) $\mathrm{ZrO}_{2}$ and (b) $\mathrm{ZrTiO}_{4}$ after calcination at $500{ }^{\circ} \mathrm{C}$

Bandgap value of $\mathrm{Cu}$-doped $\mathrm{ZrTiO}_{4}$ with $\mathrm{ZrO}_{2}$ and $\mathrm{TiO}_{2}$ is shown in Table 1. Fig. 5 shows the absorption spectra of $\mathrm{Cu}$-doped $\mathrm{ZrTiO}_{4}$ together with the references. There is a shift in absorption from the wavelength of UV-light to the visible-light region. The $\mathrm{E}_{\mathrm{g}}$ value decreased as $\mathrm{Cu}$ concentration increased until the optimum condition of $5 \%$ with the lowest bandgap in which $2.87 \mathrm{eV}$. It is believed that the composite will have more responsivity towards solar irradiation. Higher the dopant concentration of $\mathrm{Cu}$, greater the shift in absorption in comparison to the undoped $\mathrm{TiO}_{2}$ and $\mathrm{ZrO}_{2}$ [18]. While at $\mathrm{Cu}$ concentrations of 7 and $9 \%$, the absorption returned to the lower wavelength. Thus the $\mathrm{E}_{\mathrm{g}}$ value increased because of the heterojunction effect. Higher calcination temperatures of $5 \% \mathrm{Cu}$ increased the bandgap value due to sintering effect on the surface crystal of photocatalyst, so the dopant was not homogenously distributed and reduced the doping effect.

Fig. 6 presents SEM images and EDX spectra for 5\% Cu-doped $\mathrm{ZrO}_{2}$ and $\mathrm{ZrTiO}_{4}$ at calcination temperature of $500{ }^{\circ} \mathrm{C}$. The presence of $\mathrm{Cu}, \mathrm{Ti}, \mathrm{Zr}$, and $\mathrm{O}$ are shown in Table 2. The mass percentage of $\mathrm{Cu}$ on $\mathrm{ZrTiO}_{4}$ surface was higher than on $\mathrm{ZrO}_{2}$ surface. The average particles diameter was around 2-5 $\mu \mathrm{m}$. The $\mathrm{Cu}$-doped $\mathrm{ZrTiO}_{4}$ photocatalyst looked more homogenously distributed than $\mathrm{Cu}$-doped $\mathrm{ZrO}_{2}$. 
Table 2. EDX analysis of $5 \% \mathrm{Cu}$-doped $\mathrm{ZrO}_{2}$ and $\mathrm{ZrTiO}_{4}$ after calcination at $500{ }^{\circ} \mathrm{C}$

\begin{tabular}{llllll}
\hline \multirow{2}{*}{ Materials } & \multicolumn{5}{c}{ \% Mass } \\
\cline { 2 - 6 } & $\mathrm{Zr}$ & $\mathrm{O}$ & $\mathrm{Ti}$ & $\mathrm{Cu}$ & Total \\
\hline $5 \% \mathrm{Cu}$-doped $\mathrm{ZrO}_{2}$ & 69.34 & 28.20 & - & 2.46 & 100 \\
$5 \% \mathrm{Cu}$-doped $\mathrm{ZrTiO}_{4}$ & 35.22 & 38.44 & 23.02 & 3.31 & 100 \\
\hline
\end{tabular}

\section{- CONCLUSION}

$\mathrm{Cu}$-doped $\mathrm{ZrTiO}_{4}$ photocatalyst had been successfully synthesized by the sol-gel method. Cu metal dopants can affect the absorption shift of $\mathrm{Cu}$-doped $\mathrm{ZrTiO}_{4}$ to visible-light region if the added concentration does not exceed the optimum limit. The optimum concentration obtained at $5 \%$ of $\mathrm{Cu}$ concentration with $\mathrm{E}_{\mathrm{g}}$ value of $2.87 \mathrm{eV}$ after calcination temperature of $500{ }^{\circ} \mathrm{C}$ with an absorption edge of $431.93 \mathrm{~nm}$. Cu dopant inhibits the anatase formation at $500{ }^{\circ} \mathrm{C}$ calcination temperature. The presence of $\mathrm{ZrO}_{2}$ can inhibit crystal transformation at high temperatures. The materials have better visible-light responsivity as a potential photocatalyst.

\section{- ACKNOWLEDGMENTS}

We would like to express our gratitude for the financial support by DAMAS 2018 Grant (0244/J01.1.28/PL.06.02/2018) from the Faculty of Mathematics and Natural Sciences, Universitas Gadjah Mada, Indonesia.

\section{- REFERENCES}

[1] Haider, A.J., Al-Anbari, R.H., Kadhim, G.R., and Salame, C.T., 2017, Exploring potential environmental applications of $\mathrm{TiO}_{2}$ nanoparticles, Energy Procedia, 119, 332-345.

[2] Dunlop, P.S.M., Byrne, J.A., Manga, N., and Eggins, B.R., 2002, The photocatalytic removal of bacterial pollutants from drinking water, J. Photochem. Photobiol., A, 148 (1-3), 355-363.

[3] Qourzal, S., Assabbane, A., and Ait-Ichou, Y., 2004, Synthesis of $\mathrm{TiO}_{2}$ via hydrolysis of titanium tetraisopropoxide and its photocatalytic activity on a suspended mixture with activated carbon in the degradation of 2-naphthol, J. Photochem. Photobiol., 163 (3), 317-321.
[4] Yan, G., Zhang, M., Hou, J., and Yang, J., 2011, Photoelectrochemical and photocatalytic properties of $\mathrm{N}+\mathrm{S}$ co-doped $\mathrm{TiO}_{2}$ nanotube array films under visible light irradiation, Mater. Chem. Phys., 129 (12), 553-557.

[5] Khairy, M., and Zakaria, W., 2014, Effect of metaldoping of $\mathrm{TiO}_{2}$ nanoparticles on their photocatalytic activities toward removal of organic dyes, Egypt. J. Pet., 23 (4), 419-426.

[6] Hu, Q., Huang, J., Li, G., Jiang, Y., Lan, H., Guo, W., and Cao, Y., 2016, Origin of the improved photocatalytic activity of $\mathrm{Cu}$ incorporated $\mathrm{TiO}_{2}$ for hydrogen generation from water, Appl. Surf. Sci., $382,170-177$.

[7] Luo, N., Jiang, Z., Shi, H., Cao, F., Xiao, T., and Edwards, P.P., 2009, Photo-catalytic conversion of oxygenated hydrocarbons to hydrogen over heteroatom-doped $\mathrm{TiO}_{2}$ catalysts, Int. J. Hydrogen Energy, 34 (1), 125-129.

[8] Chang, S., and Doong, R., 2004, The effect of chemical states of dopants on the microstructures and band gaps of metal-doped $\mathrm{ZrO}_{2}$ thin films at different temperatures, J. Phys. Chem. B, 108 (46), 18098-18103.

[9] Fathy, A., Elkady, O., and Abu-Oqail, A., 2017, Synthesis and characterization of $\mathrm{Cu}-\mathrm{ZrO}_{2}$ nanocomposite produced by thermochemical process, J. Alloys Compd., 719, 411-419.

[10] Botta, S.G., Navio, J.A., Hidalgo, M., Restrepo, G.M., and Litter, M.I., 1999, Photocatalytic properties of $\mathrm{ZrO}_{2}$ and $\mathrm{Fe} / \mathrm{ZrO}_{2}$ semiconductors prepared by a sol-gel technique, J. Photochem. Photobiol., A, 129 (1-2), 89-99.

[11] Pirzada, B.M., Mir, N.A., Qutub, N., Mehraj, O., Sabir, S., and Muneer, M., 2015, Synthesis, characterization and optimization of photocatalytic 
activity of $\mathrm{TiO}_{2} / \mathrm{ZrO}_{2}$ nanocomposite heterostructures, Mater. Sci. Eng., B, 193, 137-145.

[12] Esposito, S., Turco, M., Bagnasco, G., Cammarano, C., Pernice, P., and Aronne, A., 2010, Highly dispersed sol-gel synthesized $\mathrm{Cu}-\mathrm{ZrO}_{2}$ materials as catalysts for oxidative steam reforming of methanol, Appl. Catal., A, 372 (1), 48-57.

[13] Chen, Q., Chang, Y., Shao, C., Zhang, J., Wang, J.M., and Long, Y., 2014, Effect of grain size on phase transformation and photoluminescence property of the nanocrystalline $\mathrm{ZrO}_{2}$ powders prepared by sol-gel method, J. Mater. Sci. Technol., 30 (11), 1103-1107.

[14] Syoufian, A., Manako, Y., and Nakashima, K., 2015, Sol-gel preparation of photoactive srilankite-type zirconium titanate hollow spheres by templating sulfonated polystyrene latex particles, Powder Technol., 280, 207-210.

[15] Andita, K.R., 2018, Synthesis of Cu-Doped $\mathrm{ZrTiO}_{4}$ with Various Percentage of $\mathrm{Cu}$ and Calcination Temperatures as a Model of Visible-Light Responsive Photocatalyst, Undergraduate Thesis, Department of Chemistry, Universitas Gadjah Mada, Yogyakarta.

[16] Nankya, R., and Kim, K.N., 2016, Sol-gel synthesis and characterization of $\mathrm{Cu}-\mathrm{TiO}_{2}$ nanoparticles with enhanced optical and photocatalytic properties, $J$. Nanosci. Nanotechnol., 16 (1), 11631-11634.

[17] Agorku, E.S., Kuvarega, A.T., Mamba, B.B., Pandey, A.C., and Mishra, A.K., 2015, Enhanced visiblelight photocatalytic activity of multi-elementsdoped $\mathrm{ZrO}_{2}$ for degradation of indigo carmine, $J$. Rare Earths, 33 (5), 498-506.

[18] Choi, J., Park, H., and Hoffmann, M.R., 2010, Effects of single metal-ion doping on the visiblelight photoreactivity of $\mathrm{TiO}_{2}$, J. Phys. Chem. C, 114 (2), 783-792. 